\title{
Keadilan sebagai Prinsip Negara Hukum: Tinjauan Teoretis dalam Konsep Demokrasi
}

\author{
Hayat*
}

\begin{abstract}
Abstrak
Keberadaan hukum ditentukan oleh perilaku, sifat, dan sikap yang berada dalam jiwa manusia sebagai kodrat berkehidupan dan bermasyarakat. Pengaturan kaidah hukum tentang tatanan manusia tidak hanya berpedoman kepada aturan baku yang diatur dalam ketentuan peraturan perundang-undangan saja, melainkan juga berpedoman kepada segala norma dan nilai moral yang melekat kepada setiap warga negara di dalam sebuah negara. Hukum dalam konteks negara Indonesia yang menganut sistem demokrasi menjunjung nilai-nilai keadilan yang ada didalamnya yang secara prinsip berkeadilan bagi seluruh rakyat Indonesia. Sebagai hukum positif dalam suatu negara hukum, penegakan hukum dituntut agar dilakukan secara profesional, proporsional, baik, adil, serta bijak sehingga sesuai dengan kaidah-kaidah kemanfaatan, kebaikan dan kesetaraan dalam hukum itu sendiri. Negara yang demokratis mengedapankan konsep keadilan hukum dalam menciptakan negara hukum yang memberikan rasa adil kepada setiap warga negaranya dengan peraturan-peraturan yang teratur dalam penegakannya, sehingga menghasilkan hukum yang baik dan berkualitas demi mencapai tujuan keadilan serta kesejahteraan bagi rakyat Indonesia seutuhnya sebagai pemegang kekuasaan dan kedaulatan negara.
\end{abstract}

Kata kunci: keadilan, negara hukum, tujuan hukum, penegakkan, demokrasi.

\section{Justice as the Principles of Law: Theoretical Review of Democracy Concept}

\begin{abstract}
The existence of the law is determined by the behavior, character, and attitude that resides in the human psyche as an existence and society nature. The regulation of the rules of law of the human order is not just hold on to standard rules stipulated in the legislation, but in relation to the norms and moral values inherent to every citizen in a country. Law in the Indonesia's context embraces democratic system upholding the values of justice that is there in, in principle, justice for all Indonesian people. As the law of the State in State law requires law enforcement professional, proportionate, fair and good and wise in the rules of expediency, kindness, and equality in the law itself. Democratic state distinguished concept of legal justice in the law state that gives a sense of justice to every citizen with regular rules in enforcement, resulting in good quality and qualified that aims to achieve justice and
\end{abstract}

PADJADJARAN Jurnal IImu Hukum Volume 2 Nomor 2 Tahun 2015 [ISSN 2460-1543] [e-ISSN 2442-9325]

* Dosen Universitas Islam Malang, JI. MT. Haryono 193 Malang, hayat.150318@gmail.com, S.AP., M.Si (Universitas Islam Malang). 
prosperity for the people of Indonesia as a whole authority and sovereignty of the country.

Keywords: justice, state law, legal purpose, enforcement, democracy.

\section{A. Latar Belakang}

Bangsa dan negara merupakan konsep riil yang memberikan pola bagi masyarakat sosial didalamnya untuk menjalankan kehidupan bernegara. Tatanan sosial masyarakat tentunya diatur secara paralel dengan ketentuan dan peraturan yang mengikat dan saling terikat antara kehidupan masyarakat secara individu atau sebagai masyarakat sosial. Peraturan dalam kehidupan sosial merupakan sebuah norma yang harus dijunjung keberadaannya dan ditaati segala konsekuensinya. Keberadaan norma dalam kehidupan sosial masyarakat tentunya menjadi tanggung jawab bersama dalam mempertahankan nilai-nilai moral dan etika yang berkelanjutan sesuai dengan kondisi lingkungan masyarakat itu sendiri, tujuannya untuk membangun masyarakat yang bertata nilai dengan prinsip keadilan dan kebaikan.

Keteraturan hidup berdasarkan norma dibangun berdasarkan ketaatan terhadap hukum yang melingkupinya, baik hukum agama, sosial, dan negara. Plato mendefinisikan hukum sebagai suatu sistem aturan-aturan positif yang terorganisir atau terformulasi, mengikat pada keseluruhan individu dalam negara. ${ }^{1} \mathrm{Hal}$ ini berarti, hukum sebagai bentuk pengaturan dalam kehidupan masyarakat secara universal dengan tidak memandang siapa yang melakukan dan prinsip ketegasan dalam sanksi yang diberikan sesuai dengan pelanggaran. Sanksi diberikan sebagai putusan akhir dari setiap pelanggaran yang dilakukan oleh warga negara sebagai wujud tanggung jawab atas segala perbuatannya. Sanksi merupakan turunan peraturan yang mengikutinya sebagai efek jera dari pelanggaran hukum yang dilakukan untuk sekiranya tidak dilakukan lagi. Pada prinsipnya, sanksi yang diberikan adalah sebagai pembinaan, pemberdayaan, dan pendidikan bagi warga negara yang memberikan pelajaran dan pengalaman agar kiranya menjadi sebuah kebaikan. Caranya adalah dengan mengubah tatanan nilai yang ada dalam diri individu di masa yang akan datang dengan harapan menjadi warga negara yang lebih baik.

Seringkali terdapat pertanyaan tentang pola pelaksanaan hukum di Indonesia sebagai negara demokrasi, juga pertayaan mengenai arah kebijakan hukum Indonesia, dan segala pertimbangan hukum yang melatarbelakangi pembentukan hukum atau penjatuhan vonis. Problematika itu merupakan sebuah gambaran

1 Herman Bakir, Filsafat Hukum: Desain dan Arsitektur Kesejarahan, Bandung: Refika Aditama, 2007, hlm. 175. 
keberadaan hukum bangsa Indonesia yang semakin tinggi. Oleh karena itu, menjadi kewajiban seluruh komponen masyarakat untuk berusaha dan memperbaiki sistem hukum sebagai kekuatan suatu negara hukum. Negara yang kuat adalah negara yang menjadikan hukum sebagai panglima, bangsa yang mandiri adalah bangsa yang menjadikan keadilan sebagai pondasi.

Pemikiran-pemikiran hukum merupakan tantangan yang harus terus dikembangkan dalam sebuah negara, terutama negara demokratis yang memberikan ruang kebebasan bagi warga negara untuk mengaktualisasikan dirinya sebagai individu dan masyarakat, dengan kebebasan yang teratur, terarah dan sistematis dengan prinsip-prinsip peraturan yang melekat dalam diri warga negara itu sendiri. Hukum tidak berjalan dengan baik tanpa ada partisipasi yang baik dari seluruh elemen negara, termasuk di dalamnya warga negara. Hukum harus dijunjung sebagai kekuatan penuh dalam penegakan dan keadilannya. Hukum harus menjadi panglima untuk menciptakan bangsa yang kuat dan maju. Hukum harus menjadi kekuatan utama dalam sistem pemerintahan sebagai benteng dan pintu utama gerbang kenegaraan.

Hukum merupakan sumber dari kebaikan dan kejayaan bangsa. Ketika hukum kuat, maka bisa dipastikan negara itu adalah negara yang kuat. Ketika hukum menjadi panglima dengan tidak tebang pilih, maka seluruh warga negara akan menjunjungnya melebihi dirinya. Ketika hukum menjadi kesatuan yang utuh bagi para penegak keadilan dalam penerapannya, maka kebaikan dan kesejahteraan bangsa ini akan tercapai dengan baik, karena dampak secara nasional dari hukum adalah ekonomi, politik, pemerintahan, dan sendi-sendi kehidupan berbangsa dan bernegara.

\section{B. Prinsip Keadilan dalam Sistem Negara Demokrasi}

Purbacaraka dan Soekanto menyebutkan sembilan arti hukum, yaitu: (1) ilmu pengetahuan, pengetahuan yang tersusun secara sistematis atas dasar kekuatan pemikiran; (2) disiplin, suatu sistem ajaran tentang kenyataan atau gejala- gejala yang dihadapi; (3) norma, pedoman atau patokan sikap tindak atau perilaku yang pantas atau diharapkan; (4) tata hukum, struktur dan proses perangkat normanorma hukum yang berlaku pada suatu waktu dan tempat tertentu serta berbentuk tertulis; (5) petugas, yakni pribadi-pribadi yang merupakan kalangan yang berhubungan erat dengan penegakan hukum (law enforcement officer); (6) keputusan penguasa, yakni hasil proses diskresi; (7) proses pemerintahan, yaitu proses hubungan timbal balik antara unsur-unsur pokok dari sistem kenegaraan; (8) sikap atau perilaku yang teratur, yakni perilaku yang diulang-ulang dengan cara yang sama, yang bertujuan mencapai kedamaian; (9) jalinan nilai-nilai, jalinan dari 
konsepsi-konsepsi abstrak tentang apa yang dianggap baik dan buruk. ${ }^{2}$

Setiap negara mempunyai peraturan yang mengikat bagi seluruh warga negaranya dalam tatanan sosial kemasyarakatan untuk ditaati dan diaplikasikan dalam kehidupan berbangsa dan bernegara sebagai konsekuensi dalam berbagai tindakan nyata sesuai dengan kontribusi yang dibangun. Tatanan nilai dalam masyarakat ditentukan oleh norma-norma yang mengatur secara paksa untuk kepentingan dan tujuan negara sebagai penyelenggara pemerintahan dan mengatur masyarakatnya secara adil dalam penegakkan hukum yang profesional dan akuntabel.

Hukum sebagai dasar aturan terhadap negara demokrasi merupakan bagian terpenting yang tidak dapat dipisahkan, karena keberadaannya mempunyai peran penting dalam berbagai tindakan yang dilakukan oleh warga negara dengan ketentuan-ketentuan hukum yang legal. Keberadaan hukum dalam konteks negara demokrasi yang harus ditegakkan di tengah-tengah kebebasan masyarakat dalam realitas sosialnya yang memberikan ruang dan lingkup yang cukup besar terhadap aspirasinya dengan tingkat keinginan dan kebutuhan serta tuntutan-tuntutan.

Prinsip keadilan dalam hukum seringkali menjadi celah bagi masyarakat untuk meminta perlakuan yang adil kepada negara sebagai penegak hukum dan pelaksana pemerintah. Keadilan seringkali ditransformasikan dalam bingkai yang keliru dalam penafsirannya, sehingga menimbulkan efek negatif dengan pembelajaran yang kurang baik terhadap masyarakat lainnya.

Hart mengemukakan, bahwa prinsip umum keadilan dalam hukum adalah kesetaraan dan ketidaksetaraan. ${ }^{3}$ Artinya bahwa untuk hal yang serupa diperlakukan dengan cara yang serupa, sedangkan untuk hal yang berbeda diperlakukan dengan cara yang berbeda. Pandangan ini memberikan persepsi bahwa kesetaraan terhadap individu harus diperlakukan sama dengan individu yang lainnya, menjadi relatif jika kesetaraan berbeda dari apa yang dilakukan terhadap cara yang diperlakukannya, begitu juga dengan perlakuan terhadap hal yang serupa dengan cara yang serupa pula.

Keadilan sebagai prinsip dasar dalam hukum tidak dapat diabaikan begitu saja dalam praktiknya, menjadi orang adil itu tidak mudah begitu juga tidak sulit, asalkan dalam diri individu mengikat jiwanya untuk berperilaku adil. Karena, pada dasarnya keadilan itu kembali kepada orang yang melakukan proses peradilan kepada orang yang diadili. Artinya, tidak setiap yang sama rata itu dikatakan adil, tergantung dari prinsip substantif perbuatan yang dilakukan. Realitas yang terjadi dalam kehidupan

2 Wayan Resmini, "Peranan Filsafat Hukum dalam Pembentukan Hukum di Indoensia”, Ganec Swara, Volume 7, Nomor 1, Maret 2013, hlm. 7.

3 Yustinus Suhardi Ruman, "Keadilan Hukum dan Penerapannya dalam Pengadilan", Humaniora, Volume 3, Nomor 2, Oktober 2012, hlm. 348. 
sosial masyarakat menjadi tidak benar jika hal yang dilakukan oleh individu itu dikatakan tidak adil, padahal sudah sesuai dengan ketentuan yang berlaku. Masyarakat terkadang kurang memahami makna keadilan itu sendiri, karena sebagai suatu substansi dari hukum yang dilakukan secara adil itu belum tentu adil bagi orang lain, begitu juga sebaliknya. Oleh karena itu, keadilan mengandung konsep relativisme baik dari segi penilaian, penglihatan, perasaan, dan persepsi, untuk menemukan makna sebenarnya dari keadilan. Keadilan tidak bisa dipandang sebagai rasa, keinginan, dan harapan, tetapi berada di dalam hati nurani masingmasing yang tidak dapat diungkapkan secara pasti.

Plato memberikan kualifikasi makna substansi dari keadilan itu, antara lain: (1) suatu karakteristik atau sifat yang terbit secara alami dalam diri setiap individu manusia; (2) dalam keadaan ini, keadilan memungkinkan orang mengerjakan pengkoordinasian (menata) serta memberi batasan (mengendalikan) pada tingkat emosi mereka dalam usaha menyesuaikan diri dengan lingkungan tempat ia bergaul; dan (3) keadilan merupakan hal yang memungkinkan masyarakat manusia menjalankan kodrat kemanusiaannya dalam cara-cara yang utuh dan semestinya. ${ }^{4}$ Keadilan merupakan sebuah sifat yang ada dalam diri manusia sebagai ungkapan atau ekspresi yang mempengaruhi di sekitarnya dalam tindakan dan karakter yang melekat kepada masing-masing individu manusia, sehingga keberadaannya ditentukan oleh penataan yang dilakukan dan pengendalian yang merupakan sebuah kunci tindakan yang akan diputuskan. Hal itu juga berkaitan dengan emosi setiap manusia dalam melakukan sebuah konsepsi keadilan dengan sifat yang melekat, sehingga dorongan dan situasi serta kondisi lingkungan juga mempengaruhi proses keadilan itu sendiri. Pandangan itu memberikan sebuah pengetahuan tentang makna substansi dari jiwa manusia yang terdesiminasikan oleh keadaan lingkungannya dengan cara-cara yang wajar sebagai manusia dengan segala kodrat yang melekat di dalamnya.

Keadilan dalam konteks hukum terkait erat dengan makna legalitas. Dikatakan adil jika peraturan yang dibuat berlaku secara sama, setara dan tanpa diskriminasi hukum yang diterapkan kepada semua kasus yang menurut peraturannya harus diterapkan. ${ }^{5}$ Legalitas secara hukum terhadap peraturan yang diberlakukan mempunyai implikasi yang sama terhadap semua perbuatan yang dilakukan dengan prinsip mengacu kepada isi dari perbuatan itu sendiri, dan dikatakan tidak adil jika penerapan dari peraturan itu tidak diterapkan pada perbuatan yang sama di tempat yang berbeda.

4 Herman Bakir, Op.cit., hlm. 177.

5 Hans Kelsen, Teori Umum Hukum dan Negara: Dasar-dasar Ilmu Hukum Normatif sebagai Ilmu Hukum DeskriptifEmpirik, terjemahan Somardi, Jakarta: Bea Media Indonesia, 2007, hlm. 15-16. 
Makna yang disampaikan oleh Kelsen merujuk kepada keadilan yang menitikberatkan terhadap tindakan yang dilakukan dengan sanksi yang diberikan. Ketika ada kasus yang sama di tempat yang berbeda, maka penerapan ketentuan peraturannya harus sama. Artinya, tidak memandang siapa yang melakukan perbuatan itu dan di mana perbuatan itu dilakukan. Sehingga, penekanan peraturan dan perbuatan itu menjadi inti dari prinsip keadilan, dengan prinsip kesamaan dalam penegakan terhadap perbuatan yang sama tidak memunculkan sebuah paradigma yang salah terhadap masyarakat.

Konsep yang ada di dalam masyarakat saat ini merupakan perbandingan terhadap nilai-nilai keadilan yang terjadi di Indonesia yang menjadi bahan ketidakadilan bagi pelaku yang sama, bahkan terhadap perbuatan yang tidak sama pula. Masyarakat menjadi pengawas dalam pelbagai konsep keadilan hukum yang diterapkan, sehingga ketika ada tindakan yang memberatkan dengan sanksi yang ringan maka dapat disimpulkan ada ketidakadilan dalam proses hukumnya. Begitu juga sebaliknya, ketika perbuatan yang lebih ringan dikenakan hukuman yang lebih berat sedangkan perbuatan yang berat dikenakan sanksi yang lebih ringan, maka ketidakadilan semakin terlihat nyata.

Teori Lon Fuller dalam Dimyati dan Wardiono ${ }^{6}$ menekankan isi hukum positif yang harus memenuhi delapan persyaratan moral tertentu, antara lain: Pertama, harus ada aturan-aturan sebagai pedoman dalam pembuatan keputusan. Hukum merupakan konfigurasi terhadap keputusan-keputusan yang diambil sebagai langkah konkret dalam penerapannya secara adil dan bijaksana sesuai dengan aturan-aturan yang legal. Keputusan-keputusan itu bukan kebijakan yang diambil secara bebas dengan otoritas hukum yang dimiliki, melainkan kebijakan yang mengikat sesuai dengan kapasitas dan kapabilitas otoritas dengan peraturan yang universal. Oleh karena itu, setiap keputusan yang diambil mempunyai kekuatan hukum yang tidak dapat diganggu gugat dan bersifat final. Dengan prinsip memberikan kewenangan dan kebebasan terhadap hak dan kewajiban terhadap keputusan yang sudah inkracht.

Kedua, aturan-aturan yang menjadi pedoman bagi otoritas tidak boleh dirahasiakan, melainkan harus diumumkan. Aturan sebagai pedoman dalam melakukan sebuah tindakan menjadi hak bersama untuk diketahui dan disosialisasikan agar sekiranya dapat dipahami secara bersama untuk membentuk sebuah persepsi yang sama dengan pembangunan paradigma secara konsepsional dan transparan terhadap peraturan yang ada, sehingga kekuatan aturan itu menekankan pengertian yang ketika dipahami secara otomatis tidak akan

6 Khudzaifah Dimyati dan Kelik Wardiono, "Pola Pemikiran Hukum Responsif; Sebuah Studi Atas Proses Pembangunan Ilmu Hukum Indonesia", Jurnal Ilmu Hukum, Volume 10, Nomor 1, Maret 2007, hlm. 4-5. 
melakukan pelanggaran terhadap aturan yang ada. Sanksi dalam aturan itu mengikat terhadap perbuatan pelanggarannya. Oleh karena itu, sudah menjadi kewajiban otoritas untuk mempublikasikan aturan-aturan yang ada untuk diketahui dan didiseminasi sebagai ketentuan yang harus ditaati secara bersama dengan menghindari segala bentuk pelanggaran aturan tersebut.

Ketiga, aturan-aturan harus dibuat untuk menjadi pedoman bagi kegiatankegiatan di kemudian hari. Hukum merupakan aturan yang menjadi pedoman dalam menjalankan hak dan kewajibannya yang berlaku pada saat ini dengan konsepsi tidak berlaku surut. Artinya, bahwa terhadap setiap perbuatan yang dilakukan saat ini diberlakukan hukum yang sedang berlaku saat ini juga, dengan prinsip pemberlakuan secara realistis dan proporsional. Sebuah perbuatan yang sudah dilakukan pada masa yang lalu, tidak bisa dijerat dengan peraturan yang diberlakukan saat ini, sehingga indvidu tersebut tidak bisa dijerat secara hukum. Oleh karena itu, pada prinsipnya hukum itu berlaku pada saat diberlakukan dengan tidak berlaku surut.

Keempat, hukum harus dibuat sedemikian rupa, sehingga dapat dimengerti oleh rakyat. Secara hierarki, rakyat mempunyai hak untuk mengetahui, memahami, dan mengerti tentang aturan hukum yang berlaku di masyarakat. Akan tetapi, masyarakat seringkali menjadi apatis terhadap aturan-aturan yang ada, kecuali aturan-aturan yang berhubungan secara langsung. Upaya tersebut pun rupanya tidak dilakukan secara proporsional, hanya informasi dari berbagai kalangan yang kurang valid kebenarannya, sehingga terkadang memberikan pemahaman yang menyesatkan bagi masyarakat itu sendiri. Merupakan kewajiban pemerintah dalam melakukan sosialisasi keberadaan aturan-aturan itu dengan berbagai pendekatan kepada masyarakat untuk diketahui bersama dan ditaati secara utuh, sehingga pelaksanaan dari hukum itu berjalan sesuai dengan harapan yang diinginkan, masyarakat sebagai objek dari hukum mempunyai kesadaran atas aturan yang dibuat oleh pemerintah. Oleh karena itu, pembuatan aturan dibuat seefisien dan seefektif mungkin dan dapat dipahami oleh semua kalangan masyarakat sehingga aplikasinya mudah diimplementasikan.

Kelima, aturan-aturan tidak boleh bertentangan satu sama lain. Keberadaan aturan dibuat untuk mengatur kehidupan masyarakat agar tersistematisasi dan terstruktur dengan baik terhadap segala bentuk tindakan dalam kehidupan masyarakat. Hal yang merugikan orang lain secara universal menjadi ketentuan yang dilarang oleh aturan, begitupun sebaliknya. Artinya, bahwa aturan itu dibuat untuk kebaikan bersama dengan pemahaman dan pelaksanaan secara bersama sesuai dengan budaya dan kebiasaan yang ada di masyarakat, sehingga aturan yang dibuat tersebut tidak bertentangan dengan kebiasaan sosial masyarakat dan aturan yang sudah berjalan. Aturan yang satu saling terintegrasi terhadap keberadaan yang 
lainnya, sehingga keberadaan berbagai aturan tersebut dapat berjalan beriringan dan bersinergi sesuai dengan etika dan nilai-nilai hukum yang ada.

Keenam, aturan-aturan tidak boleh menyaratkan perilaku di luar kemampuan pihak-pihak yang terikat di dalamnya. Setiap manusia mempunyai keterbatasan kemampuan dalam kehidupannya sesuai dengan kodrat dan fitrah yang telah dianugerahkan oleh Tuhan dengan berbagai kekurangan dan keterbatasan yang dimilikinya, tentunya manusia bertindak dan taat sesuai dengan kemampuannya. Aturan menjadi sebuah nilai pembatas dalam kehidupan manusia antara yang buruk dan yang baik, akan tetapi pembatasan itu harus diiringi oleh saksi yang mengikutinya. Aturan itu harus sesuai dengan nilai etika kehidupan masyarakat sesuai dengan keberadaan dan kemampuan yang dimilikinya, tidak memberatkan dan mengekang kehidupannya. Prinsip aturan adalah mengatur batas-batas yang tidak boleh dilakukan dan yang boleh dilakukan dengan kaidah-kaidah dan nilainilai budaya masyarakat. Sehingga keberadaannya sesuai dengan kebutuhan dan tuntutan yang ada dalam kehidupan masyarakat. Kebiasaan-kebiasaan itu bersifat relatif pula, karena antara budaya masyarakat yang satu dengan yang lainnya mepunyai ketentuan yang berbeda-beda.

Ketujuh, dalam hukum harus ada ketegasan. Hukum menjadi peraturan yang mutlak yang harus ditaati oleh setiap orang, siapa yang melanggar harus diberi sanksi sesuai dengan ketentuan yang berlaku. Hukum mempunyai nilai legalitas formal dengan ketegasan sanksi yang mengikutinya. Seringkali menjadi sebuah problematika ketika hukum sudah tidak dijadikan alat untuk mengambil sikap yang adil dalam penerapannya. Ketegasan dalam hukum menjadi keharusan dan kewajiban bagi penegak hukum, karena para penegak hukum juga mempunyai kode etik yang mengatur bagaimana memperlakukan dan memutuskan sesuatu yang berkaitan dengan aturan yang dibuat. Seringkali ketegasan hukum hanya berlaku bagi kalangan orang-orang tertentu, begitu juga ketidaktegasan hukum juga berlaku bagi masyarakat tertentu, sehingga keberadaan hukum menjadi apatisme bagi masyarakat ketika hukum bukan lagi menjadi pintu gerbang keadilan secara keseluruhan.

Kedelapan, harus ada konsistensi antara aturan-aturan sebagaimana yang diumumkan dengan pelaksanaan kenyataannya. Keputusan akan keberadaan aturan menjadi final ketika disepakati bersama oleh pemerintah dan DPR dalam menentukan aturan yang akan dilaksanakan. Siapapun harus patuh dan taat atas putusan tersebut, termasuk para pembuat aturan itu sendiri. Konsistensi menjadi tanggung jawab pemerintah dalam menerapkannya, dalam hal ini adalah para penegak hukum seperti kepolisian, pengadilan, dan kejaksaan.

Kegagalan dalam penerapan hukum yang konsisten menjadi permasalahan bagi para penegak hukum, apalagi konsistensi itu diikuti oleh pelanggaran-pelanggaran 
yang dilakukan oleh para penegak hukum. Menjadi semakin tumpul keberadaan aturan tersebut, jika para oknum pengambil keputusan dalam konteks hukum melanggar aturan itu sendiri, sehingga keberlanjutan aturannya menjadi kurang terarah dan mengubah pola pemikiran rakyat secara tidak langsung. Oleh karena itu, diperlukan sumber daya manusia yang akuntabel, jujur, adil, dan bijaksana untuk mengawal aturan-aturan hukum yang ada dengan mengembalikan fungsi hukum.

Hukum menjadi satu kesatuan dengan para penegak hukum yang tidak dapat dipisahkan oleh ruang dan waktu dalam kehidupan masyarakat. Ketika hukum menjadi aturan yang ditaati bersama oleh seluruh lapisan masyarakat, maka penegak hukum mempunyai dua lapisan aturan yang mengikat dalam dirinya, aturan yang mengatur hukum secara umum seperti aturan yang ditujukan kepada masyarakat dan aturan yang mengatur terhadap diri para penegak hukum itu sendiri yang dalam hal ini biasa disebut sebagai kode etik para penegak hukum. Moral dan etika para penegak hukum memang menjadi mutlak dimilikinya dengan kejujuran, keadilan dan kebijaksanaan karakter yang harus ditingkatkan untuk mengatur sebuah aturan hukum dapat diimplemetasikan dengan baik. Sehingga segala bentuk aplikasi hukum dapat diterapkan secara maksimal dan profesional dalam rangka menata kehidupan kehidupan masyarakat yang lebih baik dan taat akan aturan yang dibuat dengan ketentuan-ketentuan hukum yang berlaku.

\section{Penegakan Hukum di Indonesia}

Berkaitan dengan penerapan keadilan hukum dalam proses peradilan, sekurangkurangnya ada beberapa prinsip yang dapat dirumuskan, pandangan Rawls dalam Ruman 7 menjelaskan mengenai keadilan sebagai fairness. Prinsip-prinsip tersebut adalah prinsip rasionalitas, konsistensi, publisitas, dan praduga tak bersalah. Prinsip rasionalitas memberikan paradigma terhadap hukum secara baik dan benar yang mengatur individu untuk menaati segala unsur dan konsep hukum yang ada dengan meninggalkan segala larangan sesuai dengan ketentuan hukum itu sendiri, secara rasional dan sadar. Peraturan sebagai langkah tatanan bagi individu yang berakal dan bermoral merupakan ketentuan sebagai konsekuensi dari apa yang boleh dilakukan dan sesuatu yang tidak boleh dilakukan.

Bagi setiap perbuatan yang dilakukan sesuai dengan ketentuan yang berlaku akan memberikan dampak positif kepada para individu dengan reward secara moral, yakni kebaikan. Orang yang taat akan hukum dapat menjadi paradigma masyarakat secara perilaku, bahwa orang tersebut adalah orang yang baik. Begitu juga sebaliknya apabila individu melanggar ketentuan hukum, maka secara langsung ia akan mendapatkan sanksi moral dari masyarakat. Ketika pelanggaran

\footnotetext{
7 Yustinus Suhardi Ruman, Op.cit., hlm. 349-351.
} 
itu termasuk ke dalam ranah hukum pidana, maka secara otomatis ada sanksi pidana yang mengikuti perilakunya yang harus dipertanggungjawabkan.

Prinsip konsistensi menjelaskan bahwa konsistensi dalam hukum menjadi kewajiban terhadap implementasi dan penerapan hukum secara adil dan bijaksana. Begitupun sanksi yang mengikutinya harus berlaku sama sesuai dengan tingkat perilaku hukumnya. Perlakuan yang sama dan serupa terhadap setiap individu mempunyai korelasi tersendiri terhadap peraturan hukum beserta sanksinya, termasuk didalamnya prinsip-prinsip yang digunakan untuk menafsirkannya. Pengambilan keputusan peradilan dalam hukum merupakan otoritas dari penegak hukum untuk memutuskan dengan prinsip keadilan dan kebaikan bagi semua orang dengan tidak menimbulkan belenggu problematika, sehingga secara prinsip keputusan itu berlaku konsisten dan baik.

Menurut prinsip publisitas, setiap pelanggaran mempunyai ketentuan dalam hukum yang berimplikasi terhadap prinsip penegakan hukum yang berlaku, dengan acuan bahwa tidak ada pelanggaran tanpa adanya hukum (nulla crimen sine lege) sebagai sumber dari sistem hukum. Hal ini diketahui secara sadar dan jelas bersifat umum dengan kebaikan-kebaikan yang ditimbulkannya, serta tidak dipergunakan secara semena-mena dengan merugikan orang lain. Setiap pelanggaran hukum dihubungkan dengan ketentuan dan aturan yang baku, secara detail dan berkesinambungan, untuk memudahkan individu untuk mengetahui serta memberikan hak untuk mengetahui bahwa ketentuannya telah sesuai dengan konsepnya.

Ketika individu menyadari bahwa perbuatannya adalah melanggar hukum, maka secara sadar pula ia akan mengetahui realitas hukumnya untuk bertanggung jawab atas perbuatannya. Publisitas juga mempunyai dampak positif terhadap pembelajaran hukum bagi setiap individu agar dapat dipelajari dan ditaati bersamasama dalam segala tindakan dan perbuatan.

Menurut prinsip praduga tak bersalah, bahwa pelanggaran hukum merupakan konsekuensi dari perbuatan individu yang dilarang oleh hukum melalui berbagai konsepsi peraturan yang berlaku. Ketika hukum mengatakan salah, maka secara prinsip perbuatan itu adalah salah dan merupakan pelanggaran yang harus dipertanggungjawabkan. Konsekuensi dari segala perbuatan yang dilakukan, yang mengarah kepada sebuah sanksi hukum, akan diproses secara hukum sesuai dengan ketentuan dan tatanan hukumnya.

Hukum memberikan prinsip mengenai mana yang harus dilakukan dan mana yang tidak boleh dilakukan dengan ketentuan itu. Untuk menentukan keterkaitannya secara tepat dan baik untuk memastikan apakah perlakuan itu melanggar atau tidak, diperlukan sebuah pengujian perbuatan dengan berbagai instrumen yang ada dalam keteraturan hukum itu sendiri. Minimal adanya dua saksi 
terhadap perbuatan yang dianggap melanggar hukum tersebut sudah mampu memberikan sanksi hukum kepada individu yang melanggar. Keteraturan dalam pemutusan terhadap hukum, mulai dari proses penyelidikan, penyidikan hingga persidangan dan putusan mempunyai kode etik dan tata cara pelaksanaannya untuk menentukan apakah tindakan itu melanggar hukum secara nyata, ataukah hanya terjadi penyimpangan dengan tidak melanggar ketentuan hukum yang berlaku.

Kehati-hatian dalam menetapkan seseorang sebagai tersangka dalam suatu perbuatan mengarahkan para penegak hukum dan semua elemen masyarakat untuk menerapkan prinsip praduga tidak bersalah terhadap tersangka. Hal tersebut merupakan upaya penyelarasan dan pemahaman secara riil tentang tindakan tersangka agar dapat diteliti, ditelaah, dan kemudian disimpulkan menjadi sebuah keputusan dan kebijakan hukum mengenai bersalah atau tidaknya tersangka, dapat ditahan atau tidak, boleh dibebaskan atau ditahan.

Penelaahan Plato dalam konsep keadilan yang diintegrasikan ke dalam jiwa manusia secara luas dan tatanan sebuah negara, yaitu: (1) peran masyarakat dalam kehidupan berbangsa dan bernegara harus mampu memainkan fungsinya sebagai masyarakat sesuai dengan ketentuan dan perundang-undangan yang berlaku, termasuk terhadap aset ekonomi pribadinya; (2) akal atau naluri menjadi tonggak utama keadilan yang harus diletakkan pada posisi tertinggi dengan pengendalian yang sesuai terhadap ketentuan yang berlaku, maka keadilan akan diimplementasikan dengan baik mengalahkan ketidakadilan; (3) elemen masyarakat secara terpadu menjadi titik pencapaian rasa adil dalam kehidupan bermasyarakat ketika akal manusia secara rasional beserta prinsip-prinsip kemasyarakatan lainnya memandu secara bersamaan. ${ }^{8}$

Konsep hukum mengajarkan manusia untuk berbuat baik dan adil dalam mengambil keputusan, terutama di pengadilan. Sulistiyono, ${ }^{9}$ mengungkapkan bahwa untuk mendapatkan suatu keputusan yang berkualitas dan mencerminkan keadilan, hakim harus memenuhi persyaratan-persyaratan sesuai dengan UU No. 48 Pasal 27 ayat (1): Pertama, hakim harus memutus berdasarkan hukum sebagai orang yang bijaksana. Setiap keputusan hakim bersifat mengikat dan final, dalam artian keputusan itu berlaku sejak ketok palu hakim memutuskan, sehingga segala hal yang diputuskan oleh hakim tidak dapat ditolak dan disanggah dengan berbagai ketidakpuasan dan berbagai persepsi yang muncul dalam keputusan itu.

Oleh karena itu, dibutuhkan sebuah keputusan yang berkualitas bagi perkaraperkara yang dijadikan dasar keputusan hakim. Tentunya, hakim yang bijaksana

8 Herman Bakir, Loc. cit.

9 Adi Sulistyiono, "Menggapai Mutiara Keadilan: Membangun Pengadilan yang Independen dengan Paradigma Moral", Jurnal Ilmu Hukum, Volume 8, Nomor 2, September 2005, hlm. 164-165. 
akan menghasilkan putusan yang adil dan berwibawa serta dapat diterima oleh individu sesuai dengan peraturannya. Dari seorang hakim dibutuhkan sebuah kebijaksanaan dalam penerapan hukum sebagai upaya mengambil keputusan yang akuntabel dan profesional dalam berbagai persoalan hukum yang dihadapi oleh masyarakat. Kebijaksanaan tidak serta merta menjadi landasan utama atau tolok ukur bahwa hakim itu adil, akan tetapi keadilan itu tercermin dari bijaknya seorang hakim dalam memutuskan hukum.

Kedua, menguasai dan mempunyai wawasan perkembangan ilmu hukum. IImu pengetahuan merupakan suatu bekal seseorang dalam bekerja dan bertindak sesuai dengan tujuan dan harapan yang diinginkan. Begitupun seorang hakim dituntut untuk lebih cerdas dan inovatif dalam memahami berbagai perkembangan ilmu hukum yang terintegrasi dengan keadaan zaman yang berlaku dinamis.

Sesuai dengan konsep hukum, bahwa setiap peraturan-peraturan yang mengikat dengan hukum itu tidak berlaku surut. Keputusan hakim dalam menentukan sikap di pengadilan membutuhkan pengetahuan yang luas dalam pelbagai pertimbangan antara keberadaan bukti dan saksi sebagai upaya meningkatkan kualitas putusan yang adil berdasarkan prinsip hukum secara realistis dan agar dapat diterima secara universal.

Keputusan-keputusan hakim tidak serta merta sebuah keputusan yang mengandalkan keadaan saat ini, akan tetapi membutuhkan konsep pemikiran dan pelbagai keilmuan yang terintegrasi dengan ketentuan yang ada saat ini untuk menyesuaikan keberadaannya suatu perkara apakah sudah berada pada posisi yang tepat kepada tuntutan yang adaataukah problematikanya belum diatur dalam ketentuan peraturannya. Maka, dibutuhkan kejelian dengan sikap yang cerdas terhadap pemilihan referensi ilmu pengetahuan agar dapat memutuskan perkara secara bijaksana.

Ketiga, hakim tidak boleh membawa logika hukum terlalu jauh sehingga menjadi tawanan undang-undang. Rasionalitas hukum menjadi penting ketika dibutuhkan pertimbangan yang memungkinkan untuk berlaku adil dalam keputusan hukum. Keseimbangan antara logika dan ketentuan undang-undang yang mengatur diupayakan tidak menjadikan logika sebagai kekuatan penuh untuk memutuskan perkara, artinya keseimbangan hukum itu harus diklarifikasi dan didesiminasi secara benar dan akurat karena hal itu akan menjadi tawanan undangundang dalam mengambil keputusan.

Logika hukum melihat aspek rasionalitas dari perbuatan baik atau buruk secara norma dan nilai-nilai moral. Sementara undang-undang adalah ketentuan yang mengatur bentuk tindakan dengan batasan sanksi-sanksi yang mengikutinya. Undang-undang sebagai pijakan seorang hakim dalam mengambil keputusan dengan berbagai konsepsi hukum dan perkembangan ilmu hukum yang dianalisis 
secara cerdas dan bijak, termasuk menggunakan nalar rasionalitas untuk melihat konteks kekinian. Penerapan sistem pemerintahan yang demokratis menjadi bagian yang tidak dapat terpisahkan oleh naluri seorang hakim sebagai upaya rekonstruksi hukum menjadi lebih baik.

Keempat, hakim harus memahami nilai-nilai yang hidup di masyarakat. Pemikiran manusia tidak harus sama sejalan antara persepsi yang satu dengan persepsi yang lain, maka konsep kemasyarakatan sebagai budaya lokal dengan nilainilai dan norma-norma kehidupan masyarakat dapat menjadi pertimbangan hakim. Ketentuan undang-undang tidak secara merata berlaku sama terhadap masyarakat yang satu dengan masyarakat yang lainnya dalam konteks tindakan dan perbuatan yang bersifat dinamis dan abstrak. Hukum dibentuk salah satunya dengan melihat aspek budaya yang melekat dalam diri kelompok masyarakat yang bersifat tidak merugikan satu sama lainnya.

Nilai-nilai budaya mempunyai makna tersendiri dalam kehidupan masyarakat sebagai ideologi stratifikasi sosial kemasyarakatan dalam membentuk komponenkomponen kehidupan masyarakat itu sendiri. Ketentuan hakim dalam memutuskan perkara merupakan pertimbangan dari aspek budaya dan nilai kehidupan masyarakat yang ada. Tidak serta merta sesuatu yang dianggap dilarang oleh hukum menjadi mutlak untuk disalahkan, karena dalam kehidupan masyarakat ada nilai yang kadangkala tidak dipahami secara logis. Pertimbangan-pertimbangan itulah yang menjadi salah satu bagian dalam pengambilan keputusan.

Kelima, hakim tidak sekedar memeriksa masalah yang dihadapi, tapi juga berkewajiban untuk mengetahui keadaan sekitar masalah yang bersangkutan. Kehidupan masyarakat demokrasi menuntut sebuah kebebasan dalam kehidupan bermasyarakat dengan segala ungkapan dan ekspresi yang diargumentasikan secara terbuka dan bebas. Begitu juga dengan konsep hukum dalam era demokrasi yang menuntut hakim untuk mengetahui keberadaan masyarakat yang ada didalamnya dengan permasalahan yang dihadapi dan delik yang dilakukan sebagai konsepsi penguatan keputusan yang akan diambil, dengan saksi-saksi yang ada di sekitar masyarakat itu sendiri. Permasalahan sebagai kunci pelanggaran hukum yang dilakukan bukan semata-mata fokus utama, akan tetapi ruang lingkup kemasyarakatan dalam problematika itu juga perlu dipandang sebagai pertimbangan hukum.

Keenam, hakim dalam memutus perkara harus secara proposional memperhatikan keadilan, kepastian hukum, dan kemanfaatan. Keputusan hakim menjadi titik akhir keberadaan sanksi dari sebuah pelanggaran hukum yang dilakukan sesuai dengan tingkat pelanggaran yang dilakukan untuk diputuskan dengan kepastian hukum yang melekat dalam undang-undang yang mengaturnya, serta dengan asas kemanfaatan bagi putusan hakim terhadap keputusan yang sudah diambil. 
Asas keadilan menjadi sangat penting bagi seorang hakim dalam memutuskan perkara dengan berbagai pertimbangan, misalnya sanksi, tingkat perbuatan yang dilakukan, nilai dan norma yang ada di dalam masyarakat, dan alat bukti di pengadilan. Hal tersebut berorientasi terhadap asas kepastian hukum secara konsisten dan akuntabel serta asas kemanfaatan yang akan diperoleh melalui sanksi yang diberlakukan dengan konsep mendidik dan mengarahkan kepada sesuatu yang baik sebagai efek jera atas perbuatan yang dilakukan, dengan prinsip membentuk pelanggar menjadi orang yang lebih baik. Artinya, bahwa sanksi yang diberikan kepada seseorang sifatnya adalah membina perilaku yang tidak baik menjadi baik dengan berbagai pemberdayaan yang diberikan di dalamnya dengan harapan tidak mengulangi perbuatannya dan menaati segala ketentuan hukum yang ada.

Konsep hukum dibangun dan dibuat oleh sistem politik yang berlaku. Keberadaan hukum ditentukan oleh keberadaan perpolitikan. Artinya hukum itu dibuat oleh politisi yang notabene berperan sebagai aspirasi rakyat yang mempunyai kapasitas dalam menentukan dan mengatur tatanan rakyat dengan harapan konsepsi kehidupan masyarakat menjadi lebih baik. Pengaturan di sini menitikberatkan kepada kepentingan rakyat secara umum dengan prinsip pilar kebangsaan yang meliputi UUD 1945, Pancasila, Bhinneka Tunggal Ika, NKRI, serta norma-norma yang ada dalam budaya lokal kemasyarakatan sebagai acuan dibentuknya aturan hukum yang akan ditetapkan melalui kebijakan bersama dengan pemerintah.

Perkembangan paradigma hukum semakin tinggi dalam konteks negara demokrasi dengan tingkat kehidupan masyarakat yang semakin kompleks dan terbuka. Nilai-nilai hukum menjadi tumpuan utama dalam komposisi demokratisasi sistem pemerintahan negara Indonesia, sehingga dibutuhkan pola-pola penegakan hukum yang menuntut kebutuhan hukum saat ini sebagai sandaran terhadap paradigma yang berkembang. Sebagai negara hukum yang menganut sistem negara demokrasi, tentunya berbagai elemen pokok kebebasan menuntut prinsip hukum untuk disesuaikan dengan nilai-nilai dan norma-norma yang ada dengan tidak menghilangkan nilai-nilai substantif hukum itu sendiri. Hal ini penting sebagai perlakuan yang adil terhadap masyarakat demokrasi dengan transparansi yang menjadi tonggak keterbukaan hukum. Tentunya hal itu juga dilihat dari asas-asas hukum yang diharapkan secara bersama, asas keadilan, kebaikan, dan kemanfaatan.

Nurrachman memberikan konsep keadilan yang selalu disandingkan dengan rumusan-rumusan konsep hukum dalam ilmu hukum yang sesuai dengan zaman, berbagai perubahan, dan paradigma yang ada di masyarakat. Hakikatnya, keadilan adalah bentuk kata sifat dari setiap individu. Dalam konsepnya, keadilan itu berasal 
dari kata adil yang berarti tidak berat sebelah atau tidak pilih kasih sesuai dengan kebutuhan dan kesetaraan. Keadilan merupakan suatu konsep yang mengindikasikan adanya rasa keadilan dalam perlakuan (justice or fair treatment). ${ }^{10}$

Sementara itu, Huijber mengungkapkan bahwa secara historis keberadaan hukum dan keadilan bermula dari pemikiran hukum yang menuju kepada suatu aturan yang dicita-citakan dengan berbagai rancangan di negara Eropa dalam bentuk undang-undang, hanya saja hal itu tidak pernah terwujud secara utuh. Oleh karena adanya sebuah dikotomi, maka muncul dua istilah hukum itu sendiri, yaitu: (1) hukum dalam arti keadilan (iustitia) atau ius/recht yang berasal dari kata regere yang mempunyai arti memimpin. Keadilan di sini merupakan penanda bagi suatu hukum tentang peraturan-peraturan yang ada di masyarakat sesuai dengan harapan dan cita-cita bersama untuk menata kehidupan masyarakat yang lebih baik; dan (2) hukum dalam arti undang-undang atau lex atau wet. Undang-undang sebagai sarana dalam penegakan hukum secara tertulis dengan kaidah-kaidah dan norma-norma hukum sebagai perwujudan dari konsep iustitia. ${ }^{11}$

Setiardja mengungkapkan bahwa Aristoteles dalam Susilo, ${ }^{12}$ mempunyai pandangan dan pemikiran yang berbeda tentang makna keadilan secara distributif, yakni: Pertama, keadilan dalam segi-segi tertentu dalam kehidupan manusia, antara lain: (1) mengatur hubungan baik antar manusia. Kebaikan dalam kehidupan manusia mempunyai arti adil jika dilakukan dengan baik antara manusia yang satu dengan manusia yang lain dalam segala kehidupannya. Sebuah keadilan akan tercipta dari interaksi manusia secara utuh jika hal itu memberikan kemanfaatan bagi manusia lainnya; dan (2) keadilan itu terletak di antara dua kutub yang ekstrim. Kehidupan manusia ditentukan oleh kehidupan orang lain disekelilingnya yang dilakukan melalui keseimbangan dalam kepentingan dan kebutuhannya. Manusia tidak boleh mementingkan dirinya sendiri dengan melupakan kepentingan orang lain di sekitarnya.

Kedua, pembagian keadilan secara garis besar, antara lain: (1) keadilan distributif, artinya bahwa dalam kehidupan masyarakat diatur antara hubungan yang saling berkaitan antara masyarakat dengan para anggota masyarakat yang lain dengan mewajibkan pemerintah untuk memberikan hak kepada para anggota masyarakat; (2) keadilan komutatif, mengatur hubungan antar para anggota masyarakat yang satu dan anggota yang lain. Pengaturan hubungan anggota masyarakat terhadap anggota yang lain dengan ketentuan yang dicita-citakan bersama dengan mewajibkan setiap orang untuk bertindak sesuai dengan hukum

\footnotetext{
10 Agus Budi Susilo, "Penegakan Hukum yang Berkeadilan dalam Persfektif Hermeniutika Hukum: Suatu Alternatif Solusi Terhadap Problematika Penegakan Hukum di Indonesia", Jurnal Persfektif, Volume XVI, Nomor 4, September 2011, hlm. 217.

11 lbid.

12 Ibid., hlm. 219.
} 
alam dan/atau perjanjian yang telah disepakati bersama. Hal ini berkenaan dengan milik pribadi dan kepentingan pribadi.

Dijelaskan bahwa sesuatu yang menjadi milik anggota masyarakat dilakukan sesuai dengan asas kemanfaatan bagi dirinya sendiri untuk kepentingan sendiri dengan tidak merugikan orang lain dalam kehidupan bermasyarakat. Sehingga, dalam hal ini tidak ada anggota masyarakat yang dirugikan oleh aturan yang berkaitan dengan hak individu atau anggota masyarakat itu sendiri, berdasarkan kepentingan masing-masing.

Ketiga, keadilan yang menyangkut ketertiban umum, yaitu: (1) keadilan legal yang mengatur lembaga legislatif sebagai aspirator masyarakat dalam prinisip kewenangan dan kewajibannya sebagai legislator dalam membuat undang-undang yang mengatur kehidupan masyarakat secara umum, sesuai dengan kepentingan dan kebutuhan yang diharapkan dengan tujuan kesejahteraan dan keadilan bersama. Sementara, dilain pihak masyarakat diwajibkan untuk patuh terhadap undang-undang yang sudah dibuat dengan tidak melanggar peraturan-peraturan yang sudah ditentukan dan menjalani segala bentuk kewajibannya sesuai dengan perundang-undangan yang berlaku; dan (2) keadilan sosial yang mengatur hubungan antara majikan dan buruh. Pengaturan terhadap penguasa dan yang dikuasai terkait hak yang harus diterima dan kewajiban yang harus dilaksanakan untuk menjalin keseimbangan dalam kehidupan sosial masyarakat.

\section{Negara Hukum dan Hukum Negara dalam Perspektif Demokrasi}

Negara dari segala konsepsi dan fungsi serta sistemnya berasal dari bahasa Latin yaitu 'lo stato' yang mempunyai arti, antara lain: keseluruhan jabatan tetap, pejabat-pejabat dalam jabatannya, penguasa dan pengikutnya, serta wilayah yang dikuasai. Iver mengungkapkan bahwa makna negara menjadi perbincangan kontroversi para ahli. Kontroversi tersebut antara lain memandang negara sebagai struktur kelas yang menguasai kelas lain, ada pula yang menyebutkan negara didefinisikan sebagai suatu sistem kekuasaan dan sistem kesejahteraan. Ada juga mengatakan negara merupakan suatu konstruksi hukum, kemudian ada yang beranggapan bahwa negara sama dengan bangsa, sedangkan yang lainnya mengatakan bahwa negara identik dengan nasionalitas atau kebangsaan. ${ }^{13}$

Socrates memberikan gambaran tentang makna negara, yaitu susunan yang obyektif berdasarkan kepada sifat hakikat manusia. Oleh karena itu, negara bertugas untuk melaksanakan dan menerapkan hukum-hukum yang obyektif yang memuat keadilan bagi umum dan tidak hanya melayani kebutuhan para penguasa negara yang berganti-ganti. ${ }^{14}$ Negara bukanlah suatu organisasi yang hanya

\footnotetext{
${ }^{13}$ I Dewa Gede Atmadja, Ilmu Negara: Sejarah, Konsep Negara dan Kajian Kenegaraan, Malang: Setara Press, 2012, hlm. 19.

${ }^{14}$ Jum Anggriani, Hukum Administrasi Negara, Yogyakarta: Graha Ilmu, 2012, hlm. 35.
} 
mementingkan kehidupan organisasinya, akan tetapi salah satu tugas dari suatu negara adalah untuk membentuk, menjalani, dan memberikan rasa keadilan kepada setiap masyarakat dengan prinsip pelayanan bagi rakyat sebagai pemegang kekuasaan negara terhadap kebutuhan dan harapan secara bersama, dengan kedaulatan penuh yang ditumpukan kepada masyarakat secara umum. Penyelenggara negara merupakan penguasa dari pemilik negara seutuhnya, yaitu rakyat dengan segala kedaulatan yang melekat menjadi sebuah implikasi yang mewajibkan para pejabat publik untuk memaksimalkan peran jabatan yang dimiliki terhadap kepentingan rakyat.

Hakikat negara adalah suatu konsep pemikiran yang melekat secara substantif dalam diri negara itu sendiri yang didalamnya terdapat ketentuan dan elemen dasar dari negara sebagai satu kesatuan yang utuh. Atmadja, ${ }^{15}$ menambahkan bahwa dalam teori hakikat negara terdapat beberapa komponen yang melekat. Pertama, teori sosiologi. Ketentuan negara dalam teori ini dipandang sebagai suatu institusi atau lembaga negara yang mengatur, mengurusi, melayani, dan menyelenggarakan seluruh kepentingan masyarakatnya secara penuh dan bertanggung jawab. Keberadaan negara akan tetap eksis dengan pola statis yang dibangun serta terintegrasi dengan berbagai keadaan dan situasi serta kondisi zaman atau perubahan, sehingga kekokohan negara akan tetap terjaga dari segala bentuk perubahan-perubahan yang ada.

Kedua, teori organis. Organisasi negara dipandang sebagai suatu sistem pertumbuhan dalam konsep organ tubuh manusia, membutuhkan asupan energi dengan segala sistem pertumbuhan yang ada serta dengan fungsi sistem yang berlaku pada setiap organisasi negara. Negara membutuhkan ruang gerak dan hidup seperti kehidupan manusia, lahir, hidup, berkembang, dan kemudian mati sesuai dengan umur dari negara itu sendiri.

Ketiga, teori ikatan golongan. Antar golongan masyarakat mempunyai peran dan tanggung jawab bersama dalam tujuan kesejateraan bersama. Tolongmenolong antara sesama merupakan bentuk dari sosiologi kemasyarakatan yang mempunyai dampak kehidupan sosial yang lebih baik. Negara menjamin kehidupan golongan masyarakat secara undang-undang dengan mengikatkan kepada peran dan fungsinya sebagai masyarakat yang utuh.

Demokrasi mengharapkan kehidupan masyarakat yang sejahtera dan lebih baik dalam kerangka kehidupan berbangsa dan bernegara. Bentuk negara demokrasi menuntut keberadaan hukum negara mampu ditransformasikan ke dalam kehidupan yang demokratis pula sesuai dengan perkembangan sosial kemasyarakatan, akan tetapi tidak menghilangkan nilai-nilai moral yang melekat dalam diri ideologi negara itu sendiri.

\footnotetext{
15 I Dewa Gede Atmadja, Op.cit., hlm. 41-46.
} 
Indonesia sebagai negara hukum yang demokratis, menganut kedaulatan rakyat sekaligus kedaulatan hukum. Segala bentuk tindakan warga negara yang didalamnya juga terdapat penyelenggara negara mempunyai ketentuan yang sama didalam hukum negara, dengan tidak membedakan status dan sosialnya, sehingga keadilan dan kedaulatan hukum dapat dirasakan secara bersama serta kedaulatan rakyat tercipta dengan baik yang mengarah kepada kesejajaran dihadapan hukum. Konsep negara hukum adalah hierarki tatanan norma yang bermuara kepada UUD 1945 yang menjadi sumber dari segala sumber hukum dan norma kemasyarakatan sebagai acuan konstitusi. Begitu juga terhadap pelaksanaan dari negara hukum yang demokratis harus bersumber dari UUD 1945, sehingga dapat diterapkan dengan prinsip keseimbangan antar lembaga negara (check and balance system). ${ }^{16}$

Anggriani, ${ }^{17}$ menjelaskan bahwa kehidupan berbangsa dan bernegara serta bermasyarakat harus didasarkan atas hukum seperti yang dikutip dalam UUD 1945 sebelum amandemen, yang menyatakan bahwa Indonesia adalah negara hukum, bukan negara berdasarkan kekuasaan saja. Oleh karena itu, secara prinsip hukum mempunyai posisi yang paling tinggi dalam kehidupan negara atas rakyatnya yang mengatur segala bentuk kehidupan dengan tatanan yang diharapkan dapat menjaga stabilitas masyarakat dengan pengendalian-pengendalian yang ada di dalamnya. Sehingga, memungkinkan masyarakat untuk menaati segala aturan yang diberlakukan dengan prinsip keadilan yang secara penuh diterima oleh masyarakat dengan tidak ada diskriminasi antara masyarakat yang satu dengan yang lainnya.

Seperti yang disampaikan oleh Curson, bahwa negara merupakan sebuah ikhtiar yang akan membawa orang pada suatu tujuan, yakni menuju pada keadilan. ${ }^{18}$ Keadilan akan berada pada titik puncak pencapaian secara substantif, jika peran dan fungsi masyarakat diaplikasikan secara rasional dan bersama-sama mengendalikan proses kehidupan dengan kontrol-kontrol yang memuat eksistensi keadilan kedalam jiwa setiap individu, yang didalamnya terdapat aset-aset yang dimiliki oleh mereka sendiri. Lebih lanjut Anggriani ${ }^{19}$ mengungkapkan, bahwa pengertian negara hukum itu adalah: (1) negara yang berdiri diatas hukum yang menjamin keadilan kepada warga negaranya; (2) menghormati dan melindungi hakhak kemanusiaan; (3) adanya suatu mekanisme kelembagaan negara yang demokratis; (4) adanya suatu sistem hukum; dan (5) adanya kekuasaan kehakiman yang bebas.

\footnotetext{
${ }^{16}$ Martha Pigome, "Implementasi Prinsip Demokrasi dan Nomokrasi dalam Struktru Ketatanegaraan RI Pasca Amandemen UUD 1945", Jurnal Dinamika Hukum, Volume 11, Nomor 2, Mei 2011, hlm. 336.

17 Jum Anggriani, Op.cit., hlm. 37.

18 Herman Bakir, Op.cit., hlm. 178.

19 Jum Anggriani, Op.cit., hlm. 38.
} 
Keberadaan suatu negara hukum memungkinkan untuk memberikan rasa keadilan kepada masyarakatnya secara universal dengan prinsip-prinsip hukum demokrasi, sehingga keberadaan masyarakat dalam kehidupan berbangsa dan bernegara secara otomatis memberikan konsepsi pembelajaran dan pendidikan terhadap ketaatan hukum yang diharapkan karena adanya suatu hukum. Tanpa adanya kesadaran dan pengetahuan tentang hukum yang dimaksud oleh masyarakatnya secara tidak langsung akan membebani negara itu sendiri sebagai penyelenggara negara terhadap hukum dan masyarakat sebagai pihak yang seharusnya taat terhadap hukum. Mekanisme kelembagaan negara hukum juga harus mampu melindungi hak warga negaranya dari ketidakadilan dengan prinsip kemanusiaan dan saling menghormati terhadap keberlangsungan hukum yang ada. Hal itu menjadi satu kesatuan dalam sistem hukum dengan otoritas penegak hukum. Lembaga kehakiman yang secara bebas dan taat akan asas keadilan untuk memberikan pengendalian terhadap keberadaan hukum negara sebagai negara hukum.

\section{Kesimpulan}

Konsep hukum memberikan implikasi terhadap tatanan kehidupan masyarakat sebagai warga negara, terutama dalam negara demokrasi yang menjunjung kebebasan berekspresi dan berkreasi guna membentuk negara yang baik dan modern. Demokratisasi negara ditentukan oleh keberadaan prinsip keadilan didalamnya, sehingga negara yang demokratis menjadi paradigma umum. Ketika demokrasi dikaitkan dengan keadilan, bukan semata-mata adil dalam kaitannya tatanan peraturan hukum yang mengikat, akan tetapi adil dalam penggalan jiwa penegak keadilan dan jiwa-jiwa manusia secara individu yang dituntut untuk berlaku adil. Minimal keadilan dibentuk dari dalam lingkungan masyarakat itu sendiri dengan asas-asas ekonomi yang dimiliki.

Hukum yang adil sudah menjadi tuntutan sistem negara yang demokratis. Walaupun dipersepsikan bahwa hukum adalah produk politik yang menjadi sumber dari segala sumber penyelenggraan negara, akan tetapi keberlakuan hukum bersifat universal dan berlaku kepada siapa saja, tak terkecuali kepada para penegak hukum termasuk para pembuat hukum yang dalam hal ini adalah pemerintah dan lembaga legislatif sebagai representasi dari negara demokrasi seperti Indonesia.

Negara Indonesia sebagai negara yang demokratis dengan konsensus hukum yang ada, mengantarkan tatanan hukum yang lebih fleksibel dan dinamis, serta penegakan secara demokratis terhadap persepsi bahwa setiap warga negara Indonesia mempunyai hak konstitusi dalam peraturan perundang-undang sebagai pemegang kekuasaan penuh negara. Secara teoretis penegakan hukum di 
Indonesia masih memiliki titik lemah dalam penerapannya. Dengan berbagai konsepsi yang ada dan kendala yang dihadapi oleh para penegak hukum dan masyarakat secara umum dalam tataran aturan yang diberlakukan menjadi sedikit apatis dengan tingkat kepercayaan yang semakin luntur dan keyakinan yang semakin pesimis terhadap penegakan hukum di Indonesia.

Demokratisasi negara menuntut perlakuan hukum untuk berlaku adil seadiladilnya, karena negara demokrasi memberikan ruang yang sangat luas bagi setiap warga negara untuk menuntut keadilan kepada para penegak hukum. Konsekuensi yang dihadapi adalah kewajiban bersama untuk memberikan kontribusi nyata terhadap penegakan hukum di Indonesia, dengan pemikiran dan substansi dari kondisi lingkungan bangsa Indonesia untuk lebih baik dan adil. Keadilan dalam konteks hukum negara Indonesia menjadi harapan bersama sesuai dengan amanat UUD 1945 dan Pancasila sebagai ideologi bangsa.

\section{Daftar Pustaka}

\section{Buku}

I Dewa Gede Atmadja, Ilmu Negara: Sejarah, Konsep Negara dan Kajian Kenegaraan, Setara Press, Malang, 2012.

Herman Bakir, Filsafat Hukum: Desain dan Arsitektur Kesejarahan, Refika Aditama, Bandung, 2007.

Jum Anggriani, Hukum Administrasi Negara, Graha Ilmu, Yogyakarta, 2012.

Kelsen, Hans, Teori Hukum dan Negara: Dasar-Dasar IImu Hukum Normatif Sebagai Ilmu Hukum Deskriptif-Empiris, ter. Somardi, Bee Media Indonesia, Jakarta, 2007.

\section{Dokumen Lain}

Adi Sulistyiono, "Menggapai Mutiara Keadilan: Membangun Pengadilan yang Independen dengan Paradigma Moral, Jurnal IImu Hukum, Volume 8, Nomor 2, September 2005.

Agus Budi Susilo, "Penegakan Hukum yang Berkeadilan dalam Persfektif Hermeniutika Hukum: Suatu Alternatif Solusi Terhadap Problematika Penegakan Hukum di Indonesia", Jurnal Persfektif, Volume XVI, Nomor 4, September 2011. 
Khudzaifah Dimyati dan Kelik Wardiono, "Pola Pemikiran Hukum Responsif; Sebuah Studi Atas Proses Pembangunan IImu Hukum Indonesia", Jurnal IImu Hukum, Volume 10, Nomor 1, Maret 2007.

Pigome, Martha, "Implementasi Prinsip Demokrasi dan Nomokrasi dalam Struktur Ketatanegaraan RI Pasca Amandemen UUD 1945", Junal Dinamika Hukum, Volume 11, Nomor 2, Mei 2011.

Wayan Resmini, "Peranan Filsafat Hukum dalam Pembentukan Hukum di Indonesia", GaneÇcSwara, Volume 7, Nomor 1, Maret 2013.

Yustinus Suhardi Ruman, "Keadilan Hukum dan Penerapannya dalam Pengadilan", Humaniora, Volume 3, Nomor 2, Oktober 2012. 